\title{
Restoring the 'historical deficit': The exercise of the right to freedom of religion and culture in democratic South Africa
}

\author{
Patricia Michelle Lenaghan
}

\begin{abstract}
On 18 January 1960, LIFE magazine began a series of articles on democracy around the world. The newly independent nation of Ghana (1957) was featured in Part 1 and the cover photograph was of Augustus Molade Akiwumi, the Speaker of the House in Ghana, dressed in British-style wig and robes. The title of the feature article read, 'Ghana's Leap from Stone Age to Eager New Nationhood'. The feature explains that in Ghana 'Courts are being built, and in lower courts the temporary local judges are being replaced with more qualified appointees to settle local disputes and initiate the people in the mechanics of Western justice'. However in stark contrast to the portrayal of pre-colonial Ghana as 'Stone Age' the Asanti peoples of Ghana developed a complex, hierarchical society and legal system centuries before Europeans ever arrived on the continent. In critical reflection of the magazine cover, this article is founded on demonstrating how the colonial, post-colonial, apartheid and post-apartheid state have through an oppressive stance suppressed indigenous religious and cultural diversity. In addition, it is asserted that the current constitutional arrangements have not at all times effectively dealt with this subjugation. It is presupposed that unless a positive approach towards religious and cultural integrity is displayed and an environment is created in which these rights to freedom of religion and culture may prosper, the constitutional endeavour of establishing unity and solidarity in our diverse society will remain elusive. In conclusion, some approaches to enhancing this constitutional endeavour are proffered.
\end{abstract}

\section{Introduction 1}

Colonial and post-colonial suppression of indigenous religious and cultural diversity as well as the oppressive relationship of the colonial and apartheid state has done much in minimising the value and importance of indigenous religious and cultural systems. It is contended that the current constitutional arrangement has not at all times adequately addressed this underestimation of indigenous religious and cultural diversity. This

\footnotetext{
${ }^{1}$ This article is based on a paper presented at the Symposium on Religious Rights and Freedoms, jointly organised by the Faculty of Law, University of the Free State and the South African Institute for Advanced Constitutional, Public, Human Rights and International Law (a centre of the Faculty of Law, University of Johannesburg) in collaboration with Juta \& Co Ltd, September 2011, Constitutional Hill, Johannesburg, South Africa.
} 
devaluation has further been aggravated through the modern inclination towards urbanisation. $^{2}$

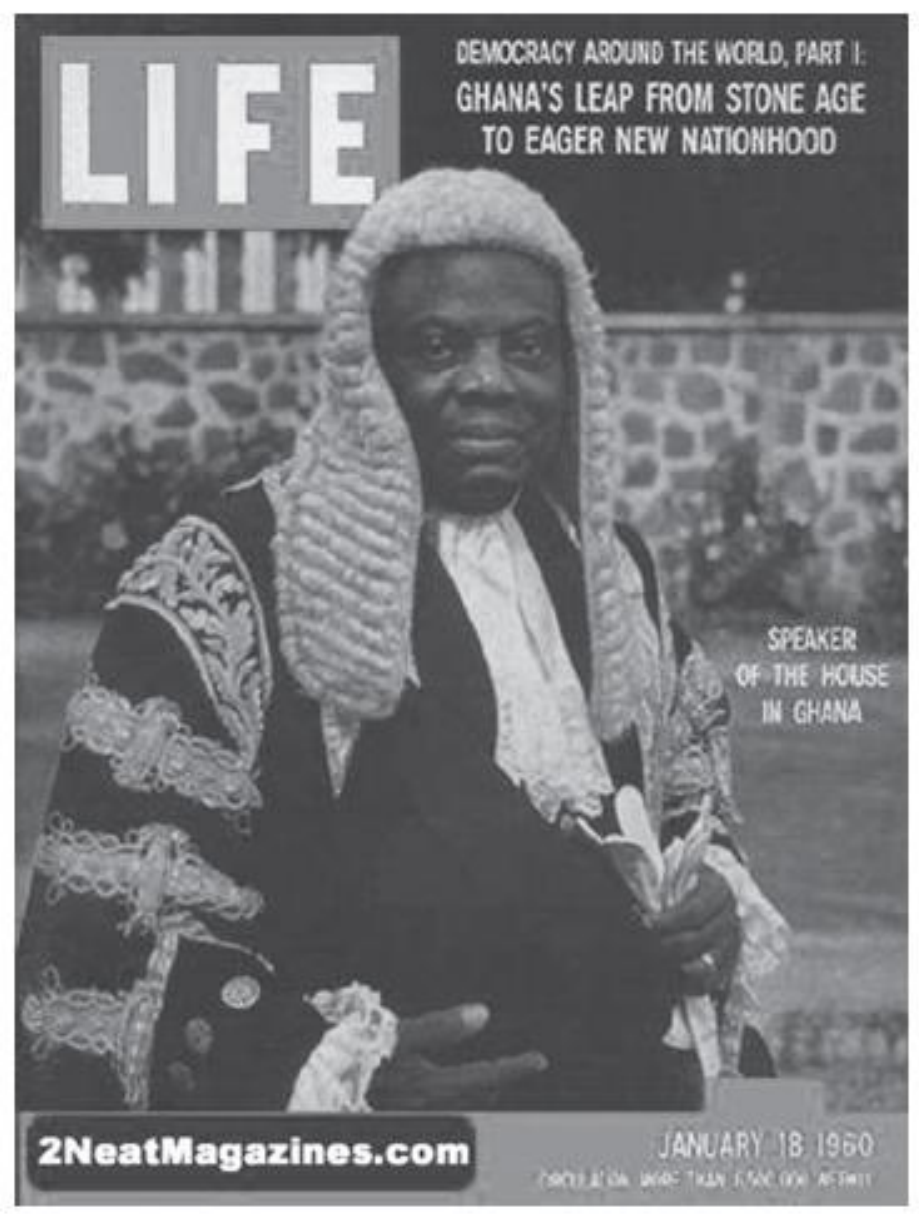

Source: Life Magazine Cover Photograph (18 January 1960), available at $<\mathrm{http}: / / \mathrm{www} .2$ neatmagazines.com/Life-Magazine-Covers/1960/Life-Magazine-1960-01-18.jpg>

Consequently, a traditional cultural practice such as Umkhosi Wokweshwama, (celebration of the first fruits) practised amongst the Zulu people, in which a beast is killed to mark the first fruits before the crops are harvested, has been negatively assessed. In the light of this and other forms of legal and moral criticism of indigenous religious and cultural practices, this article will argue that for the right to freedom of religion and culture to be adequately protected the interrelated nature of these rights must be appreciated.

This article will firstly set out how the concepts of religion and culture are interrelated. Thereafter the article will illustrate how religion and culture in South Africa have been entwined with the economic, social, and political relations of power that have privileged some, but have excluded many others. 3 The domination of the Christian Protestant faith in

\footnotetext{
${ }^{2}$ Within the scope of this article the impact of urbanisation, as well as other influences such as racial segregation and separation of the land, on traditional cultural and religious values will not be explored.

${ }^{3}$ D Chidester Religions of South Africa (1992) xi.
}

\section{http://repository.uwc.ac.za}


particular brought about many incidents of conflict with indigenous culture and religion. 4 This oppressive attitude has done much in minimising the value and importance of indigenous religious and cultural systems. In addition, it is suggested that this delegitimisation has not at all times been addressed effectively by the current constitutional arrangement. Finally, some suggestions on how to ensure that the constitutional endeavour of establishing unity and solidarity in our diverse society is attained are put forward.

\section{Interrelated nature of the concepts of 'religion' and 'culture'}

Religion is not defined in the Constitution of the Republic of South Africa, 1996. Similarly, there is no generally accepted definition for religion in international law that may be of assistance. 5 However, Peter Edge and Graham Harvey provide the following definition: 'Religions are diverse ways of being human and there are many various ways of being religious. All are concerned with ways of seeing and being in the world.' 6 In line with this definition of religion being a way of seeing and being in the world, this article proceeds from an alternative approach to defining the concept of religion, in terms of which the value of the role of religion in the lives of adherents is recognised, through emphasising the various 'facets' of religion. ${ }^{7}$ Three 'facets' can be identified: firstly, religion as a belief; secondly, religion as a way of life; and thirdly, religion as an identity. Religion as a belief accentuates, for example, the existence of a deity or the adherence to doctrines. The second 'facet' of religion accentuates religion as a way of life. In this facet religion is associated with actions and rituals that may distinguish the believer from adherents of other religions. The traditional Christian view of religion focuses primarily on religion as belief and, moreover, religion as a private belief. ${ }^{8}$ For adherents of other religions, the belief component may be of less importance. Religion, as a way of life, may perhaps be the most salient aspect of their lives. For example, adherence to their religion may impose certain social practices, for example that certain dietary requirements, religious dress or grooming requirements be complied with.

In terms of the traditional Christian view of religion, western states are reluctant to make accommodations for this religious way of life and in doing so often reveal the dominant facet of the religion of the majority of the state as a religion of belief. 9 These states may claim that by enforcing so called laws' that are applicable to all religious and ethnic groups, the state laws' that are applicable to all religious and ethnic groups, the state is treating all religions as equal. However, adherents to religion as a way of life may suffer disproportionately. This may have a devastating impact on the individual's ability to practise

\footnotetext{
${ }^{4}$ At the same time European Christianity itself became the endorsed worldview in Africa. In this regard see Chidester Ibid 37 . In addition, missionary teachings undermined the political authority of chiefs and subverted the social order of African societies. See Chidester Ibid 44.

${ }^{5}$ Neither the International Covenant on Civil and Political Rights (1966) nor the European Convention on Human Rights (1950) developed detailed definitions. See generally MW Janis \& C Evans (eds) Religion and International Law (1999); P Cumper 'Freedom of Thought, Conscience and Belief' in D Harris \& S Joseph The International Covenant on Civil and Political Rights and United Kingdom Law (1995).

${ }^{6} \mathrm{PW}$ Edge \& G Harvey Law and Religion in Contemporary Society Communities, Individualism and the State (2000) 8-9.

7 JT Gunn 'Definition of "Religion” in International Law' (2003) 16 Harvard Human Rights LJ 189, 200.

${ }^{8}$ Ibid 204.

${ }^{9}$ Ibid 205.
} 
her religion. ${ }^{10}$ For these reasons it is necessary to find alternative approaches to defining religion.

\section{(a) Religion as identity}

None of the international or national instruments mentioned previously provide for a specific right to identity. Consequently, no definition for the right to identity exists. The South African Constitutional Court in the matter of Pillay, ${ }^{11}$ however, convincingly reasons for the importance of identity as follows: 'Dignity and identity are inseparably linked as one's sense of self- worth is defined by one's identity.' 12

Identity is therefore linked to the self-worth of an individual. The importance of selfworth is appreciated by John Rawls who speaks of a 'sense of belonging. ${ }^{13}$ A sense of belonging is made possible through the individuals' location in, for example, a religious or cultural community. Religion as identity accentuates affiliation with a group, such as ethnicity, race or nationality. Religion as identity is accepted by Elizabeth Benito, ${ }^{14}$ who holds that 'religion usually encompasses more than faith. Often it is the focal point of the cultural tradition of a group'. ${ }^{15}$ In this regard it can be said that for many believers religious practices may form the core component of their personal identity or the identity of the given community to which they belong. Although religion is usually concerned with personal faith and culture typically relates to traditions of a community, there can be an overlap between the two, as custom often develops in line with a community's spiritual beliefs. Cultural beliefs may be as strongly held as religious convictions. For example, dress codes that may have been religiously prescribed may simultaneously be the focal point of identification of the cultural group. In addition, it is sometimes impossible to separate defining characteristics of a group's cultural composition, as religious belief is often an

integral part of ethnicity. ${ }^{16}{ }^{16}$ Both religion and ethnicity play an important role in people's self-identity. Religion may further form the foundation of the existence of a specific ethnic group as supported by the following definition of ethnic group as a group of people who are seen as:

[S]haring a distinctive and enduring collective identity based on a belief in a common origin, a common history and a common destiny [as well as] culturally specific practices and beliefs. Physical appearance, language, a shared territory and religious beliefs may further contribute in varying degrees to ethnic identity. ${ }^{17}$

\footnotetext{
${ }^{10}$ Ibid 214.

${ }^{11}$ MEC for Education KwaZulu-Natal v Pillay 2008 (1) SA 474 (CC); 2008 (2) BCLR 99 (CC).

${ }^{12}$ Ibid para 53 (own emphasis added).

13 J Rawls A Theory of Justice (1971) 62. See also I Berlin Four Essays on Liberty (1969) 154-60.

${ }^{14}$ EO Benito, Special Rapporteur on the Elimination of All Forms of Intolerance and Discrimination Based on Religion or Belief for the period 1983 to 1986.

${ }^{15}$ Report of the Special Rapporteur on the Elimination of All Forms of Intolerance and Discrimination Based on Religion or Belief, Sub-Commission on the Prevention and Protection of Minorities, Commission on Human Rights, Economic and Social Council, 39th session para 183 UN Doc E/CN.4/Sub 2/1987/26/(1986).

${ }^{16}$ J Haynes 'Religion, Secularisation and Politics: A Postmodern Conspectus' (1997) 18 Third World Quarterly $709,721$.

${ }^{17}$ A Odendaal Ethnic Conflict and its Management: A Position Paper'. Centre for Conflict Resolution (1998) 1.
} 
Identity consequently relates to various distinctive characteristics such as language, culture and religion; these aspects are all relative. However, the very nature of universal human rights prefers to deal with universalities and generalities. ${ }^{18}$ Consequently, the importance of these relative attributes is often insufficiently considered. Regarding the definition of religion as identity, it is further important to acknowledge the cultural and ethnic interconnection.

\section{(b) Cultural, ethnic and racial interconnection of identity}

The interconnection between race and religion is suitably portrayed among the people in the Cape during the 17th and 18th centuries. Religion rather than race provided the categories for defining differences. Religion was also often interlaced with ethnicity or nationality. For example Muslims in the Cape were referred to as 'Malays'.19 In Natal too, ethnicity or nationality was attached in a similar manner. Muslim merchants from India settling in Natal set themselves apart from Indian labourers, who were mostly Hindu, through calling themselves 'Arabs'.20

Religion, race, ${ }^{21}$ and ethnicity ${ }^{22}$ are all types of cultural groupings. The concept 'cultural group' refers to a group of people who to a large extent share similar customs, lifestyles, values, religious beliefs, historical continuity, physical characteristics and/or language. ${ }^{23}$ The overlap between ethnicity and religion has also been recognised by Abdelfattah Amor, United Nations Special Rapporteur on Freedom of Religion or Belief, who states that:

$[\mathrm{T}]$ he distinctions between racial and religious categories ... are not clear ... There are borderline cases where racial and religious distinctions are far from clear-cut. Apart from any discrimination, the identity of many minorities, or even large groups of people, is defined by both racial and religious aspects. Hence, many instances of discrimination are aggravated by the effects of multiple identities ... ${ }^{24}$

The importance of religion and ethnicity (or race) is situated in the fact that religion and race not only have significance for the individual within the framework of the religious belief system or biological foundation of race. Religion and ethnicity (or race) create a collective identity as well, which has a cultural and social significance for the individual. ${ }^{25}$ Therefore, race, ethnicity and religion are indicative of the individual's self-identity as well

\footnotetext{
${ }^{18}$ C Douzinas 'Identity, Recognition, Rights or What can Hegel Teach us About Human Rights?' (2002) 29 J of Law and Society 379 , 402.

${ }^{19}$ In this regard see Chidester (note 3 above) 162 where he refers to a comment in the 1860 s by an aristocratic English visitor to the Cape, Lucy Duff Gordon.

${ }^{20}$ F Ginwala 'Class, Consciousness and Control: Indian South Africans, 1860-1946'. DPhil thesis, Oxford University (1974) 136.

${ }^{21}$ The term race or racial group usually refers to the categorisation of humans into populations or ancestral groups on the basis of various sets of heritable characteristics. The physical features commonly seen as indicating race are salient visual traits such as skin colour, cranial or facial features and hair texture.

${ }^{22}$ Ethnicity like race is concerned with the notion of descent or genealogy. The terms 'ethnicity' and 'ethnic group' are derived from the Greek word ethnos, normally translated as 'nation' or commonly said of people of the same race that share a distinctive culture.

${ }^{23}$ Y Tseming 'Race, Religion, and Cultural Identity: Reconciling the Jurisprudence of Race and Religion' (1997) 37 Indiana LJ 119, 127.

${ }^{24}$ UN Special Rapporteur on Freedom of Religion or Belief, A Amor 'Racial Discrimination and Religious Discrimination: Identification and Measures' [29] UN Doc A/CONF.189/PC. 1/7(2000).

${ }^{25}$ Tseming (note 23 above) 123.
} 
as of the individual's sense of belonging to a cultural community. Consequently, the similarities between race, ethnicity and religion are located within the fact that all play comparable roles in determining the position of an individual as well as a cultural community within society. ${ }^{26}$

The interrelated nature of religion and culture as well as the role thereof in the cultural community, as reasoned for above, is also confirmed by the African Commission on Human and Peoples' Rights in the matter of Endorois Welfare Council $v$ Kenya. ${ }^{27}$ In this matter, the indigenous Endorois community was displaced from their ancestral lands by the Kenyan government through the gazetting of the Lake Bogoria Game Reserve. Of relevance for this article are the alleged violations of the Endorois community's right to practise their religion ${ }^{28}$ and culture. ${ }^{29}$ The Endorois claim their health, livelihood, religion and culture are all intimately connected with their traditional land, as grazing lands, sacred religious sites, historical prayer sites, places for circumcision rituals, and other cultural ceremonies are all situated around the shores of Lake Bogoria..$^{\circ}$ The Endorois believe that spirits of all former Endorois, no matter where they are buried, live on in the lake. $3^{1}$ The lake is therefore essential to the religious practices and beliefs of the Endorois. ${ }^{2}$ By restricting access to Lake Bogoria, access to a central element of Endorois cultural practice has been denied. The African Commission confirms that the concept of indigenous peoples recognises the linkages between peoples, their land, and culture and that such a group expresses its desire to be identified as a people. 33 The African Commission is further of the view that Endorois culture, religion, and traditional way of life are intimately intertwined with their ancestral lands - Lake Bogoria and the surrounding area. It agrees that Lake Bogoria is central to the Endorois' way of life and without access to their ancestral land, the Endorois are unable to fully exercise their cultural and religious rights, and feel disconnected from their land and ancestors. 34 The Commission is aware that religion is often linked to land, cultural beliefs and practices. 35 The Commission therefore holds the view that denying access to the lake is a restriction on their freedom to practise their religion 36 and a violation of cultural rights in that the community has faced systematic restrictions on access to cultural sites. 37

\footnotetext{
${ }^{26}$ Ibid 121.

${ }^{27}$ Centre for Minority Rights Development (Kenya) and Minority Rights Group (on behalf of Endorois Welfare Council) $v$ Kenya African Commission on Human and Peoples' Rights 276/03 (Endorois).

${ }^{28}$ Article 8 of the African Charter on Human and Peoples' Rights states 'Freedom of conscience, the profession and free practice of religion shall be guaranteed. No one may, subject to law and order, be submitted to measures restricting the exercise of these freedoms'.

${ }^{29}$ Articles 17(2) \& (3) of the African Charter on Human and Peoples' Rights states '(2) Every individual may freely take part in the cultural life of his community. (3) The promotion and protection of morals and traditional values recognised by the community shall be the duty of the State'.

${ }^{30}$ Endorois (note 27 above) para 16.

${ }^{31}$ Ibid para 79.

${ }^{32}$ Ibid para 16.

${ }^{33}$ Ibid para 151.

${ }^{34}$ Ibid para 156.

${ }^{35}$ Ibid para 166.

${ }^{36}$ Ibid para 173.

${ }^{37}$ Ibid para 239.
} 
From the above discussion it is apparent that the African Commission too appreciates the interrelated nature of religion and culture, which the Commission confirms as follows:

It thus understands culture to mean that complex whole which includes a spiritual and physical association with one's ancestral land, knowledge, belief, art, law, morals, customs, and any other capabilities and habits acquired by humankind as a member of society - the sum total of the material and spiritual activities and products of a given social group that distinguish it from other similar groups. It has also understood cultural identity to encompass a group's religion, language, and other defining characteristics. 38

This article concurs with the above appreciation of the interrelated nature of religion and culture. It further maintains that the interrelated nature of religion and culture is a positive step in creating an environment in which, in particular, the right to indigenous religions and cultures may prosper. However, this awareness further requires a consciousness regarding the impact of historical domination on indigenous cultural and religious diversity, as discussed next.

\section{The impact of historical religious and cultural domination on indigenous cultural and religious diversity and in particular customary law}

The presence of Christianity in South Africa can be traced to the arrival of the Dutch East India Company in 1652. The Cape Colony, under the Dutch East India Company prohibited any other religion at the Cape besides the Dutch Reformed Church until 1778.39 The history of religious conflict in South herefore is symbolic of, in particular, the domination of the Protestant herefore is symbolic of, in particular, the domination of the Protestant faith. Examples of discriminatory behaviour against other faiths are plentiful. For example, permission to build the first Muslim mosque was only granted in 1798.40 Traditional African religion too was not left untouched from the influence of Christian domination, and the Christian mission became a space for the endorsement of a particular European Christian worldview in Africa. ${ }^{41}$ The bias towards the Protestant faith was also prevalent in the actions of the local authorities. For example, in 1856, municipal authorities in Cape Town banned the annual religious festival of Khalifa (also known as Ratiep) as 'dangerous to the law and peace of the community'. ${ }^{2}$ During the festival Muslim devotees enacted a show that included self-torture by way of sticking sharp spears or swords through their bodies.

\footnotetext{
${ }^{38}$ Ibid para 241.

${ }^{39}$ At this time the religion of slaves was determined in terms of an ordinance (1770) that prohibited the buying or selling of slaves who had converted to Christianity. In light of this prohibition, slave-owners excluded their slaves from Christian conversion or baptism in order to retain property rights over them. In this regard see Chidester (note 3 above) 35. See generally P Coertzen 'Freedom of Religion in South Africa: Then and Now 1652-2008' (2008) 29 Verbum Et Ecclesia J 345.

${ }^{40}$ Chidester (note 3 above) 151.

${ }^{41}$ Ibid 37.

${ }^{42}$ Ibid 162.
} 
The domination of the Protestant faith also violated the communal expressions of traditional African religions 43 and individual conscience of Africans. The traditions and religions of Africans were alluded to as being from the Stone Age, and therefore subverted. In doing this many Africans have been deprived of essential elements of their humanity.44 This paternalistic approach deemed, for example, African dances, marriage ceremonies and actions of worship as incompatible with Christianity. Through a process of continued acculturation African religions have in many instances suffered harm or destruction. 45

Nonetheless, the abandonment of indigenous culture and religion did not occur. Over time colonial courts where permitted to apply customary law in so far as it was "not repugnant to the general principles of humanity observed throughout the civilised world'. 46 To ease the application in colonial courts various systems of customary law were written to code. 47 In due course, traditional leaders and native commissioners were appointed to adjudicate over civil customary disputes. ${ }^{48}$

However, the various systems of customary law were not applied uniformly throughout the territories. 49 For example, in the previous Transvaal customary marriages and lobolo agreements were not recognised on the basis that polygamy and the payment of a 'bride price' was uncivilised.50 With the merger to a Union ${ }^{1}$ the need to develop an integrated approach was evident. The Native Administrations Act 38 of 1927 was introduced to recreate traditional authority in terms of which customary law was applied in separate systems of courts by traditional leaders and native commissioners. The recognition of customary law was associated with race and the application was considered subordinate to the legal system of the Union.

It is clear that customary law was not fully recognised as a component of the South African legal system. Traditionally, customary law was at best treated with indifference ${ }^{2}$ or

\footnotetext{
43 This paternalistic approach was not only directed towards African religions but also targeted the fields of medicine, politics and economics. MW Mutua 'Limitations on Religious Rights: Problematizing Religious Freedom in the African Context' in JD van der Vyver \& J Witte Jr (eds) Religious Human Rights in a Global Perspective Legal Perspectives (1996) 417, 428.

${ }^{44}$ Ibid 418. See also generally JS Pobee 'Africa's Search for Religious Human Rights through Returning to the Wells of Living Water' in Van der Vyver \& Witte Ibid 391

${ }^{45}$ Ibid 420. For a differing perspective see generally L Van der Poll 'The Impact of Traditional Sex Practices on the Construction of Female Sexuality: An African Human Rights Perspective’ (2009) 13 Law, Democracy \& Development 1.

${ }^{46}$ Proclamation 110 \& 112 of 1879 s 23.

${ }^{47}$ Codification was favoured by colonist and lawyers who wanted the Rule of Law applied. However, as M Chanock Making of the South African Legal Culture 1902-1936; Fear Favour and Prejudice (2000) 249 argues, the effect of codification was to 'shift control of African law away from African and place it in the hands of white administrators and magistrates'.

${ }^{48}$ EH Brookes The History of the Native Policy in South Africa from 1830 to Present Day (1924) 130.

${ }^{49}$ Cape, Natal, Transvaal and Orange Free State.

${ }^{50}$ See Meesadoosa v Links 1915 TPD 357, 358. The non-recognition of potentially polygamous marriages was first entrenched in 1912 when a South African court ruled that all polygamous marriages, permitted in both Hindu and Muslim practice, were illegal in South Africa. See generally A Kerr 'Back to the Problems of a Hundred or More Years Ago: Public Policy Concerning Contracts Relating to Marriages that are Potentially or Actually Polygamous' (1984) 101 SALJ 445. Regarding the illegality of Muslim marriages see Esop v Union Government (Minister of the Interior) 1913 CPD 133. In the case of Esop it was held by the court that 'Mariam is in law the concubine and not the wife of the applicant'. Consequently numerous Indian wives were reduced to concubines. Gandhi interpreted the judgment to imply that all marriages not concluded in terms of Christian rites were null and void. In this regard, see generally W le Roux 'Conscience Against the Law: Mahatma Gandhi, Nelson Mandela and Bram Fischer as Practising Lawyers During the Struggle' (2001) XXXXII CODICILLVS 36.

${ }^{51}$ The Union Constitution (South Africa Act 1909 (9 Edw VII, c 9)).

52 TW Bennett Customary Law in South Africa (2008) 35.
} 
at worst not recognised.53 Adherents were persuaded to abandon their tribal ways in preference of Christianity and at first a Dutch and later a British conception of civilisation, 54 reminiscent of the crude cover of LIFE Magazine titled 'Ghana's Leap from Stone Age to Eager New Nationhood'.

This bias was formally corrected with the passing of the interim Constitution ${ }^{55}$ and confirmed in the final Constitution. ${ }^{6}$ The onset of the interim Constitution was engineered to bring change to the subordination of indigenous religious and cultural diversity.57 The South African Constitution is the supreme law of South Africa and any law inconsistent with the provisions contained therein is invalid. ${ }^{8}$ Chapter 2 contains a Bill of Rights, which is the cornerstone of the democracy and enshrines the rights of all the while affirming the democratic values of human dignity, equality and freedom. 59 The right to freedom of religion is specifically included as a fundamental right of everyone ${ }^{60}$ and is extensively referred to throughout the Constitution. ${ }^{61}$ The right to culture too is specifically included as a fundamental right of everyone. ${ }^{62}$ Furthermore, the right of persons belonging to cultural, religious or linguistic communities to enjoy their culture, practice their religion and use their language is referred to in the Constitution.63 The state must accordingly tolerate and allow for different cultural practices, may not discriminate against any cultural group and must preserve the identity of the group. Cultural groups must be allowed to promote their own autonomous identity. Section 31 contains an internal limitation, which determines that the right to culture may not be exercised in a manner inconsistent with the provisions of the Bill of Rights.

Courts are also now constitutionally obliged to apply customary law. Section 211(3) provides that the courts must apply customary law when that law is applicable, subject to the Constitution and any legislation that specifically deals with customary law. Accordingly, customary law is placed on an equal footing with the Roman Dutch Legal System. When applying customary law, s 39(2) provides that every court, when interpreting or developing

\footnotetext{
53 Ibid.

${ }^{54}$ Ibid 36.

55 The Interim Constitution of the Republic of South Africa Act 200 of 1993, which came into force on 27 April 1994. The interim Constitution was the result of negotiations between the representatives of the apartheid state and its opponents. Interim Constitution s 14.

${ }^{56}$ Constitution ss $15,30 \& 31$.

${ }^{57}$ For a general overview of religious human rights in South Africa before and shortly after the first democratic elections in 1994 see generally LM du Plessis 'Religious Human Rights in South Africa' in Van der Vyver \& Witte (note 43 above) 441; see generally LM du Plessis 'Religion, Law and State in South Africa' (1997) 4 European J for Church and State Research 221.

${ }^{58}$ Constitution s 2 .

${ }^{59}$ See Constitution s 7(1) which provides: 'The Bill of Rights is a cornerstone of democracy in South Africa. It enshrines the rights of all people in our country and affirms the democratic values of human dignity, equality and freedom'. The drafting of the South African Constitution was influenced by libertarians focusing on individual liberty while egalitarians emphasised equality as the central value. The tension between a libertarian and an egalitarian approach is also prevalent in the discourse pertaining to the right to freedom of religion and the right to manifest religious beliefs that may be limited.

${ }^{60}$ Constitution s 15.

${ }^{61}$ See the Preamble of the Constitution as well as s 6 which includes within the linguistic rights 'Arabic, Hebrew, Sanskrit and other languages used for religious purposes', s 15 which guarantees the right to freedom of religion, s 16, which contains a general freedom of expression clause, does not apply to advocacy of hatred based on race, ethnicity, gender or religion where it constitutes incitement to cause harm. See also ss 31, 35, 48, 95, 107, $135 \&$ schedule 2 of the Constitution.

${ }^{62}$ Constitution s 30 .

${ }^{63}$ Ibid s 31.
} 
customary law the spirit of the Bill of Rights must be promoted. The spirit of the Bill of Rights relates to the values of human dignity, equality and freedom. For this reason no discussion of the right to freedom of religion and the right to freedom of culture is complete without reference to human dignity and equality.

\section{Dignity and equality in relation to the application of the right to religion and culture}

The role of religious and cultural practices in relation to human dignity and equality is confirmed in that: '[R]eligious and cultural practices are protected because they are central to human identity and hence to human dignity which is in turn central to equality.' 64 Laurie Ackerman too has advocated that dignity e highly valued as a constant reminder of our past of inequality and discrimination. 65 The impact of the past of inequality and discrimination on the value of indigenous cultural and religious practices has been reflected on. This article therefore next turns to the importance of dignity and equality.

With regard to dignity, Stuart Woolman identifies the following relevant definitions. ${ }^{66}$ First, dignity is defined as a means of allowing the individual to consider herself as an end-in herself. This notion is in reaction to the domination of the past and the attempts to deny many the 'right of self-identification and self-determination'.67 Second, dignity is defined as acknowledging the notion of equal concern and equal respect. This approach allows for the right to equality to play a relevant role in the recognition of the definition of dignity as equal concern and respect.

Accordingly, there clearly is an interrelation between dignity and equality. In this regard Christian Education South Africa $v$ Minister of Education affirms that equality does not require that we treat everyone in the same way, but that we treat everyone with equal concern and equal respect. ${ }^{68}$ Goldstone $\mathrm{J}$ confirms this interrelation between dignity and equality as follows:

[A]t the heart of the prohibition of unfair discrimination lies a recognition that the purpose of our new constitutional and democratic order is the establishment of a society in which all human beings will be accorded equal dignity and respect regardless of their membership in particular groups. 69

A third meaning of dignity is related to dignity as self-actualisation. This notion is confirmed by Ackerman who expresses this understanding of dignity as follows 'An individual's human dignity cannot be fully respected or valued unless the individual is

\footnotetext{
${ }^{64}$ Pillay (note 11 above) para 62.

${ }^{65}$ LWH Ackerman 'The Legal Nature of the South African Revolution' New Zealand Law Review (2004) 633, 650

${ }^{66} \mathrm{~S}$ Woolman 'Dignity' in S Woolman \& M Bishop Constitutional Law of South Africa 2 ed (2008) 6.

${ }^{67}$ Ackerman (note 65 above) 649.

${ }^{68} 2000$ (10) BCLR para 42.

${ }^{69}$ The President of the Republic of South Africa v Hugo 1997 (4) SA 1 (CC) para 41.
} 
permitted to develop his or her unique talents optimally'.70 Further ways of defining dignity relate to self-governance and the collective dignity of the group.

In particular, dignity defined in relation to self-identification, self-determination and selfactualisation, allowing the individual to develop optimally and permitting the individual the ability to give meaning to her life is relevant to both the right to freedom of religion and culture. Similarly, dignity defined in relation to the equal concern and respect of an individual is closely associated with the value and right to equality. From these definitions it is clear that both equality and dignity are of importance when applying the right to freedom of religion and the right to freedom of culture.

Dignity is however not only defined in different ways, but operates in different respects as well. Dignity may function as a specific right, for example the right to dignity, as entrenched in s 10.71 Additionally, dignity may determine how the entrenched right is applied. To illustrate this determination, in the application of the right to equality, the test to determine if an infringement occurs, requires an investigation into whether or not the differentiation results in an impairment of human dignity, which then may determine if the differentiation amounts to actual discrimination. Dignity may also function as a correlative right, in that there is a relationship between the right to dignity and individual freedom, as affirmed in the Hugo case as follows: '[D]ignity is at the heart of individual rights in a free and democratic society ...'72

Dignity is most often referred to as a value or Grundnorm. The reason, therefore, is that various provisions in the Bill of Rights and the rights themselves must be interpreted so as to "promote the values that underlie an open and democratic society based on human dignity, equality and freedom'.73 In South Africa, Drucilla Cornell contends that a substantive revolution has inverted the order of apartheid, which denied the dignity of the black majority, by making the respect for the dignity of all others the Grundnorm of the entire Constitution. 74

Dignity therefore stands in relation to the application of all other rights and these rights shape our understanding of dignity. For that reason dignity has particular relevance to our understanding of the right to freedom of religion and culture. Similarly, the right to equality is of particular relevance to our appreciation of the right to freedom of religion and culture. The interrelationship between dignity and equality in many ways can be comparable to the interrelation that exists between religion and culture as illustrated previously. For diversity to prosper it is essential that the value of dignity and equality as

\footnotetext{
${ }^{70}$ Ferreira $v$ Levin 1996 (1) SA 984 (CC) para 49.

${ }^{71}$ Woolman (note 66 above) 19.

72 President of the Republic of South Africa v Hugo 1997 (6) BCLR 759 (CC) para 41.

${ }^{73}$ Constitution s 36 (limitations provision) \& s 39 (interpretative provisions).

${ }^{74}$ D Cornell 'The Significance of the Living Customary Law for an Understanding of Law: Does Custom Allow for a Woman to be Hosi?' (2009) 2 Constitutional Court Review 395, 400. Cornell refers to Hans Kelsen who describes substantive revolution as a term to describe all legal transfer of power where the reigning government gives up its sole hold on state authority. See generally H Kelsen General Theory of Law and the State (1945).
} 
well as the interrelation between religion and culture are held when addressing issues regarding the manifestation of indigenous culture and religion, in particular.

\section{$V$ The manifestation of indigenous religion and culture in a democratic South Africa}

Counter to the colonial model that predicted the disappearance of indigenous culture and religion, these practices continue today, alongside modern systems of law and religion. Nonetheless, the impact of colonisation on these practices remains prevalent, as it is often more difficult to erase the permeation of subordination on the manner in which the right to freedom of religion and the right to culture is evolving in South Africa. In this regard Martin Chanock confirms that law was a major tool utilised by the European colonisers as an instrument of the power of an alien state and part of the process of coercion. 75 Existing legal systems and culture therefore represent the unequal distribution of power. As shown previously, this unequal representation of power is especially prevalent in the application of customary law, the law by which millions of people live and who respect its dictates.

The South African Constitution recognises customary law and provides that '[t]he courts must apply customary law when that law is applicable, subject to the Constitution and any legislation that specifically deals with customary law'.76 The South African Constitutional Court has recognised the subordination of the past and has shown appreciation of diversity as follows:

Value of acknowledging diversity and pluralism in our society ... affirm[ed] the right of people to self-expression without being forced to subordinate themselves to the cultural and religious norms of others, and highlight[ed] the importance of individuals and communities being able to enjoy what has been called the 'right to be different'. 77

The question of how to determine what the customary law is, is however crucially important.78 Van der Westhuizen $\mathrm{J}$ recognises in Shilubana $v$ Nwamitwa that the stagnation of customary law was inevitable under apartheid.79 However, flexibility of the living customary law must be balanced against other factors such as legal certainty, vested rights and the protection of constitutional rights under the new dispensation. The Constitutional Court has therefore distinguished between the so-called 'codified' customary law and the 'living' customary law as experienced by those living within the custom. ${ }^{80}$ Appreciation of the fact that the content of rights may change over time is central to the jurisprudence in the South African Constitutional Court as well as to the issue of how the content of living customary law should be ascertained. Normally the source of living customary law is related back to the ancestors. Therefore, although the living customary

\footnotetext{
${ }^{75}$ M Chanock Law, Custom, and Social Order The Colonial Experience in Malawi and Zambia (1998) 4.

${ }^{76}$ Constitution s 211(3).

${ }^{77}$ Minister of Home Affairs v Fourie 2006 (1) SA 524 (CC) para 61.

${ }^{78} 2009$ (2) SA 66 (CC) para 43.

${ }^{79}$ Ibid 45.

${ }^{80}$ A Claassens \& S Mnisi 'Rural Women Redefining Land Rights in the Context of Living Customary Law' (2009) 25 SAJHR 491, 503.
} 
law can evolve and change, and indeed certainly has been changing, the question of change is complex.

In this regard Thandabantu Nhlapo alerts to the fact that legal elites may have deeply internalised values of modernisation and westernisation to the extent that they may at times be unwilling to share an ethical space with alternative world views, which may be consistent with the respect for the dignity of all persons in South Africa. ${ }^{81}$ Furthermore, as De Villiers has claimed, the examination thereof must be met with caution as it all too often leads us back to the customary law that was inscribed by the colonisers of South Africa. ${ }^{82}$ In light of the above, this article therefore maintains that the manner in which the content of customary law is determined is especially vulnerable. This vulnerability is related to the fact that customary practices, ceremonies and rituals tend to reflect a value system that challenges western principles and provides fertile ground for rights-based critiques. It is, in particular, the possible responses to these rights-based critiques that this article seeks to identify. This article reasons that conflict within legal systems could be utilised to destabilise current certainties and allows for alternative ways of interpretation to be revealed. In the search for alternative ways of interpretation this article relies on the indeterminacy of all rights claims, which is illustrative of the debate about what 'the society is and what it ought to be'.83 In so far as the social is constructed and revolves around a set of choices that have been made. Accordingly, any understanding of the social should centre on appreciating that nothing is necessary and that everything is contingent. ${ }^{84}$ The appreciation of the interrelated nature of religion and culture is related to this understanding. This article further has revealed the tensions within the legal system and the ideological and material forces that underpin them. In so doing the sense of necessity in legal doctrine has been weakened and the need to re-create the legal system by showing that 'it exists in a cultural context' in which society is understood to be made and imagined, rather than given, is highlighted. 85

The need to transform society is also founded and confirmed in the provisions of both the interim ${ }^{86}$ and final Constitution. In this regard it has been remarked that:

Our Constitution encompasses a transformative provision. As such, the State cannot be a passive bystander in shaping the society in which individuals can fully enjoy their rights? [T] he full transformative power of the rights in the Bill of Rights will only be realised when

\footnotetext{
${ }^{81}$ T Nhlapo 'The African Customary Law of Marriage and the Rights Conundrum' in M Mamdani (ed) Beyond Rights Talk and Culture Talk Comparative Essays on the Politics of Rights and Culture (2000) 136, 146.

${ }^{82}$ For a distinction between codified and living customary law, see generally E Grant 'Human Rights, Cultural Diversity and Customary Law in South Africa' (2006) 2 J of African Law 13-7. See also AJ Kerr 'Role of Courts in Developing Customary Law' (1999) Obiter 41.

${ }^{83}$ M Tushnet 'An Essay on Rights' (1984) 62 Texas LR 1363, 1370.

${ }^{84}$ Ibid 1402.

${ }^{85}$ DP Visser referring to R Unger 'The Critical Legal Studies Movement' (1983) Harvard LR 561 in 'The Legal Historian as Subversive or Killing the Capitoline Geese' Essays in the History of Law 20.

${ }^{86}$ The Postamble to the interim Constitution provides the basis. The Epilogue describes the Constitution as providing: 'a historic bridge between the past of a deeply divided society characterised by strife, conflict, untold suffering and injustice, and a future founded on the recognition of human rights, democracy and peaceful co-existence and development opportunities for all South Africans, irrespective of colour, race, class, belief or sex'.
} 
they are interpreted with reference to the specific social and economic context prevalent in the country as a whole, and the social and economic context within which the applicant now finds itself in particular. ${ }^{87}$

To this end Pius Langa has remarked that transformation is not only the duty of the judiciary, but that transformation must be coupled with legislative reform and executive action together with the social transformation of society. 88

\section{Transformation and the living customary law}

The judgment in Bhe $v$ Magistrate, Khayelitsha89 rejects 'official customary law' as a 'poor reflection, if not a distortion of the true customary law'. It holds that '[t]rue customary law will be that which recognises and acknowledges the changes which continually take place'..$^{\circ}$ The need for change is also emphasised by Moseneke $\mathrm{J}$ in Gumede $v$ President of the Republic of South Africa where he states that 'during colonial times, the great difficulty resided in the fact that customary law was entirely prevented from evolving and adapting as the changing circumstances of the communities required'. 91

Regarding the evolving nature of customary law, the Constitutional Court in Shilubana held that:

As has been repeatedly emphasised by this and other courts, customary law is by its nature a constantly evolving system. Under pre-democratic colonial and apartheid regimes, this development was frustrated and customary law stagnated. This stagnation should not continue, and the free development by communities of their own laws to meet the needs of a rapidly changing society must be respected and facilitated..$^{2}$

Nonetheless, as Cornell cautions, customary law is a very different notion of doing law, and indeed doing justice, than the one we have developed in the West.93 In this claim she is supported by John Murungi who has argued that African jurisprudence has an entirely different view of law as the doing of justice. According to Murungi:

What is essential to law is what secures human beings in their being. The pursuit and the preservation of what is human and what is implicated by being human are what, in a particular understanding, is signified by African jurisprudence. 94

Not only does living customary law differ in all the fundamental aspects, such as the source, the process as well as the actual outcome, from the western concept of law in South

\footnotetext{
${ }^{87}$ City of Johannesburg v Rand Properties (Pty) Ltd 2006 (6) BCLR 728 (W) paras 51-2.

${ }^{88}$ P Langa 'Transformative Constitutionalism' (2006) 3 Stellenbosch LR 351, 358.

${ }^{89} 2005$ (1) SA 580 (CC).

${ }^{90}$ Ibid 86.

${ }^{91} 2009$ (3) SA 152 (CC) para 20.

${ }^{92}$ Shilubana (note 78 above) 45.

${ }^{93}$ Cornell (note 74 above) 405.

${ }^{94}$ J Murungi ‘African Jurisprudence: Hermeneutic Reflections' in K Wiredu (ed) A Companion to African Philosophy (2006) 525-6.
} 
Africa. 95 But also, principles of customary law, such as ubuntu have a profound effect on the actual rules and processes that guide legal conflict. The African concept of ubuntu, that means constituted by and through relationships with others has been explained by Mokgoro $J$ as follows:

Generally, ubuntu translates as 'humaneness'. In its most fundamental sense it translates as personhood and 'morality'. Metaphorically, it expresses itself in umuntu ngumuntu ngabantu, describing the significance of group solidarity on survival issues so central to the survival of communities. While it envelops the key values of group solidarity, compassion, respect, human dignity, conformity to basic norms and collective unity, in its fundamental sense it denotes humanity and morality. .96

Ubuntu therefore represents a philosophy of life, which views the individual's existence and well-being relative to that group of which he or she is a part. The spirit of ubuntu is a part of the cultural heritage of the majority of the population that combines individual rights with a communitarian philosophy of human interdependence, respect and concern. 97

In an effort to reconcile these different notions, Jennifer Nedelsky's work demonstrates that in practice rights act not as boundaries to protect autonomy, but as means of structuring relationships of interdependence in an unequal world. Therefore rights have a changing and a contested quality. All rights claims must be appreciative of the manner in which rights are defined. Central to any rights discourse therefore must be an appreciation of the fact that what rights do and have always done, is construct relationships, of power, or responsibility. ${ }^{98}$ Nedelsky further describes rights as 'collective decisions about the implementation of core values'. 99 Therefore democracy is the consent to an equal voice in the determination of these collective choices of core values. ${ }^{100}$ Adherents to religious and cultural values in a democracy for this reason must be afforded a role to frame their own rights claims ${ }^{101}$ under conditions of genuine freedom rather than minimum standards. ${ }^{102}$ Nedelsky's point of view entails that we should move away from an understanding of rights as having predetermined boundaries, and be aware of the processes of negotiation about underlying values that change the content of rights over time. Any definition of rights must therefore acknowledge that people live in a context of legal and cultural pluralism in which these values should be allowed an equal voice in the determination of rights. ${ }^{103}$ In this regard Louise Vincent ${ }^{104}$ refers to what Deborah Posel ${ }^{105}$

\footnotetext{
${ }^{95} \mathrm{C}$ Himonga \& C Bosch 'Application of African Customary Law under the Constitution of South Africa: Problems Solved or Just Beginning' (2000) SALJ 306, 318.

${ }^{96} S$ v Makwanyane 1995 (3) SA 391 (CC) para 308.

${ }_{97}$ Port Elizabeth Municipality v Various Occupiers 2004 (12) BCLR 1268 (CC) para 37.

${ }^{98}$ J Nedelsky 'Reconceiving Rights as Relationship' (1993) 1 Review of Constitutional Studies 13.

99 J Nedelsky 'Reconceiving Rights and Constitutionalism' (2008) 7 J of Human Rights 139.

${ }^{100}$ Ibid 143-4.

${ }^{101}$ S Fredman 'Engendering Socio-Economic Rights' (2009) 25 SAJHR 410, 411. In this article Fredman argues that women have a role in framing their rights claims.

${ }^{102}$ Expanding on Amartya Sen and Martha Nussbaum's capabilities approach.

${ }^{103}$ C Nyamu-Musembi ‘Are Local Norms and Practices Fences or Pathways? The Example of Women's Property Rights' in AA AnNa'im (ed) Cultural Transformation and Human Rights in Africa (2002) 126-50.

${ }^{104}$ L Vincent 'Virginity Testing in South Africa: Re-Traditioning the Postcolony' (2006) 8 Culture, Health \& Sexuality $17,19$.
} 
has called 'contending moral worlds'. In the one world the rational, rights-bearing, inherently valuable individual is placed at the centre, while the other suggests that a valuable person is something one becomes and that one's relationship to others is central to this process of becoming. This process of becoming is also referred to as 'African humanism'106 or within African tradition as ubuntu.

The moral world of ubuntu is in stark contrast with liberalism's autonomous, rationallychoosing individual subject. This contrast within the discourse on human rights is also often contained in the larger debate about universalism and cultural relativism. ${ }^{107}$ However, these 'contending moral worlds' may exist simultaneously within the individual. In this regard John and Jean Comaroff have talked of a 'dual' or colonial subject, at once liberal, at once tribal. ${ }^{108}$ As a result, there concurrently exists an aspiration to build on the indigenous, as well as recognition that the indigenous may present a challenge in a liberal democratic state dominated by market individualism. ${ }^{109}$ These 'contending moral worlds' are not only prevalent in the colonial subject, but also in the South African nation-building discourse. The concept of the 'rainbow nation' reflects a community of difference; however the notion of diversity contains within itself the potential for conflict or social disorder and consequently the impulse to homogenise.

Vincent further avers that in South Africa the need to turn to ethnic tradition is particularly strong by those who regard themselves as excluded or disadvantaged under the new order, excluded for example from the state's contractual obligations to the secure economic benefits for its citizens. ${ }^{110}$ Vincent argues that the reinstatement of practices such as virginity testing must be seen as part of a broader move for the revival of 'indigenous knowledge systems' suppressed during the apartheid era. ${ }^{111}$ Conversely, this counter narrative of return according to Vincent depicts an imaginative universe rather than a 'real' one.112 In this regard the practice in its reinstated form has been claimed to have lost its essence in that the practice has been rendered profitable with the introduction of a fee for each test and certificate. In this regard Aninka Claassens and Sindiso Mnisi claim that the dangers posed by national legislation that reinforces the power of traditional leaders to unilaterally define custom can be addressed through customary law being defined as 'living law' that is able to reflect changing practice. ${ }^{113}$

\footnotetext{
${ }^{105}$ D Posel 'Afterword: Vigilantism and the Burden of Rights: Reflections on the Paradoxes of Freedom in Post-apartheid South Africa' (2004) 63 African Studies 231, 231.

${ }^{106}$ L Praeg African Philosophy and the Quest for Autonomy (2000) 267.

107 On cultural resistance to universal claims regarding human rights, see generally T Franck 'Is Personal Freedom a Western Value?' (1997) American J of Int Law 593. For an alternative viewpoint see generally H Kwasi Prempeh 'Marbury in Africa: Judicial Review and the Challenge of Constitutionalism in Contemporary Africa' 80 (2006) Tulane LR 1239. The debate related to universalism and cultural relativism will not be explored within the context of this article.

${ }^{108}$ J Comaroff \& J Comaroff (eds) Modernity and its Malcontents Ritual and Power in Postcolonial Africa (1993) 62. See also generally J Comaroff \& J Comaroff 'Reflections on Liberalism, Policulturalism, and ID-ology: Citizenship and Difference in South Africa' (2003) 9 Social Identities 459.

${ }^{109}$ Vincent (note 104 above) 25-6.

${ }^{110}$ Ibid 27.

${ }^{111}$ Ibid.

${ }^{112}$ Ibid.

${ }^{113}$ See generally Claassens \& Mnisi (note 80 above) 491.
} 


\section{Review of reinstated indigenous cultural and religious practices}

The Pietermaritzburg High Court in the matter of Stephanus Smit NO v His Majesty King Goodwill Zwelithini Kabhekuzulu114 held that the traditional practice of Umkhosi Wokweshwama, their bare-handed killing of a practice of Umkhosi Wokweshwama, their bare-handed killing of a bull may go ahead. ${ }^{115}$ The practice is a well-known, annual event and is a symbolic way of thanking God for the first crops of the season. The court held that the applicants' grounds for seeking an interdict were ill-informed and based on a distorted view of the tradition of Umkhosi Wokweshwama. In essence the applicants sought to portray the Zulu people as barbaric, uncultured and inhuman, subjecting animals to cruel forms of torture under the auspices and encouragement of their King in the name of custom and tradition. The court further held that had the applicants possessed more understanding of other people's cultures they might have been more judicious in accepting without question the truth of the sensational and baseless press release by a Kenyan-based animal rights organisation. On dismissing the application Van der Reyden $J$ held that he was satisfied with the evidence of cultural expert Professor Jabulani Mapalala that the Animals Rights Africa's objection to the ritual was based on untrue information and hearsay in that none of the persons who deposed to affidavits before this court had witnessed the ceremony. ${ }^{116}$ In responding to the ruling KwaZulu-Natal Premier Zweli Mkhize said 'We want to promote freedom of worship and religion. Our Constitution was designed specifically to protect all cultures and customs practised by our people'. ${ }^{117}$

Similarly in January 2007, Tony Yengeni, former chief whip of South Africa's governing party, the African National Congress (ANC), celebrated his early release from a four-year prison sentence by slaughtering a bull at his father's house in the Cape Town township of Gugulethu. ${ }^{118}$ This African ritual was performed in order to gratify the Yengeni family ancestors. Animal rights activists, however, decried the sacrifice as an act of unnecessary cruelty. ${ }^{119}$ In response the Minister of Arts and Culture, Pallo Jordan, called for a proper understanding of African cultural practices and Jody Kollapen, the chair of the Human Rights Commission, said 'the slaughter of animals by cultures in South Africa was an issue that needed to be dealt with in context. Cultural liberty is an important right'. ${ }^{120}$ The singular portrayal of the Zulu people as barbaric, uncultured and inhuman, in that they subject animals to cruel forms of torture as well as condemnation of animal sacrifice as an act of unnecessary cruelty, as illustrated above, are both mindful of the article in LIFE in which the need to appoint qualified appointees to initiate the Ghanaian people from the Stone Age to a new Nationhood was emphasised.

\footnotetext{
1141023 KZNPD (2009).

115 'Bull-killing Ruling Promotes "Cultural Tolerance" $\quad$ Legalbrief (7 $\quad$ December 2009) <http://www.legalbrief.co.za/article.php?story=2009120715454354>.

116 'Allowing bull killing promotes tolerance' iol news (4 December 2009) <http://www iol.co.za/news/south-africa/allowing-bullkilling-promotes-tolerance-1.466773?ot=inmsa.ArticlePrintPageLayout.ot>.

${ }^{117}$ Ibid.

118 'Yengeni Animal Slaughter not Criminal - SAHRC' iol news (23 January 2007) <http://www.iol.co.za/news/south-africa/yengenianimal-slaughter-not-criminal-sahrc-1.312056\#.UZNqKqJIjII>.

$119 \mathrm{~J}$ Amoah \& T Bennett 'The Freedom of Religion and Culture Under the South African Constitution: Do Traditional African Religions Enjoy Equal Treatment?' (2008-2009) 24 J of Law and Religion 1.

${ }^{120}$ See note 118 above.
} 
It is evident that in these examples the adherents to religious and cultural values have been eager to frame their own rights claims. In response to these rights claims the state has a duty of even-handedness and non-identification. The relationship between the state and religion (and culture) should resemble an even-handed ${ }^{121}$ interaction between the state and religion. In the interpretation of this even-handed interaction, the right to freedom of religion (and culture) should be interpreted as a liberty and an equality right. The state should therefore refrain from favouring one religion (or culture) over others and should react impartially towards all religions. Coupled with the duty of even-handedness and non-identification, the state has a duty to respect, protect, promote and fulfil the rights entrenched in the Bill of Rights.122 The state, therefore, has both a negative duty of noninterference, as well as a positive duty to act in the interests of religious freedom and cultural integrity, so that the rights to freedom of religion and culture may flourish.

In exercising these positive obligations it is advised that the state and the institutions of the state should acknowledge that people live in a context of legal and cultural pluralism in which these values should be allowed an equal voice in the determination of rights. ${ }^{123}$ In allowing an equal voice for all, the establishment of a totalised system is avoided and an end to an anaemic understanding of human nature is promoted. ${ }^{124}$ In this regard Richard Sherwin illustrates that throughout history, totalised systems have produced disarray. To illustrate this point he refers to the story of Babel that was reduced to rubble in response to the objective of imposing a totalised dialect upon the inhabitants. Sherwin claims that the parable illustrates how the capacity to actively engage in civil society through a multiplicity of discourses shows a way to escape self-destruction. ${ }^{125}$ Sherwin refers to the quest for the acknowledgment of others as follows:

Justice speaks otherwise. It occurs in the presence of, and in response to, the infinite demand of the Other. This response, and the unremitting responsibility to which it leads, marks the origin of sociality. Justice in this sense finds its model in the ethical sublime: the human capacity, rooted in the self-transcendence of poetic imagination, to let beings and Others be. ${ }^{126}$ In being responsible for the demands of the Others in the world according to Sherwin marks the origin of ethics. ${ }^{127}$ Sherwin continues further arguing 'Responsibility for the Other, and the third, who dwells beside the one I face, generates the

\footnotetext{
${ }^{121}$ Regarding the even-handed approach see Lawrence v The State, Negal v The State, Solberg v The State 1997 (4) SA 1176 (CC); 1997 (10) BCLR 1348 (CC) (Lawrence). This case dealt with religious freedom, contained in s 14 of the interim Constitution. The wording of s 14 is similar to the wording of s 15 of the final Constitution. The principles regarding s 14 would therefore also apply to s 15 of the final Constitution. This matter was an appeal from criminal convictions in terms of the Liquor Act. The Court had to consider whether certain provisions of the Liquor Act 27 of 1989, which prohibit the sale of liquor on Sundays, were unconstitutional in terms of the provisions of s 14 of the interim Constitution. The majority of the Court held that the provisions were constitutional. In Lawrence, O'Regan J (para 122) held that the relationship between the state and religion should display an even-handed approach. See also generally JD van der Vyver 'Constitutional Perspectives of Church-State Relations in South Africa' (1999) Brigham Young Univ LR 635. The relationship between the state and religion will not be explored further in the confines of this article.

${ }^{122}$ Constitution s 7(2)

${ }^{123}$ Nyamu-Musembi (note 103 above).

${ }^{124}$ RK Sherwin 'Sublime Jurisprudence: On the Ethical Education of the Legal Imagination in our Time' (2008) 83 Chicago-Kent LR 1157, 1193.

${ }^{125}$ Ibid 1192. See also generally RK Sherwin 'Dialects and Dominance: A Study of Rhetorical Fields in the Law of Confessions' (1988) 136 Univ of Pennsylvania LR 729.

${ }^{126}$ Sherwin (note 124 above) 1189.

${ }^{127}$ Ibid 1190.
} 
bond on the basis of which society is held together'. ${ }^{128}$ It is only when the demands of the Other are acknowledged that the full spectrum of humanity be allowed to cast the shadow of an anaemic understanding away.

\section{Conclusion}

There ought to be in any rights discourse an appreciation of the fact that what rights do and have always done, is construct relationships, of power, or responsibility. ${ }^{129}$ In reaching collective decisions about the implementation of core values ${ }^{130}$ an equal voice in the determination of these core values ought to be provided. Some possible approaches that have been proffered include the constitutional Grundnorm of dignity as well as the principles of customary law, such as ubuntu. Therefore, the freedom to practise one's religion or custom requires that a balance be struck between protecting and imposing cultural values.

In the renegotiation of rights, there ought to be an awareness of underlying values that change the content of rights over time. In addition, there ought to be awareness of the contending moral worlds that exist within the individual who frames her rights. This internal conflict may indeed further be exacerbated by the state's failure to serve the most basic elements of the state's contractual obligations, such as with regard to the maintenance of law and order or the securing of economic benefits for citizens. In the event of failures such as these the temptation of those who regard themselves as excluded or disadvantaged to turn to re-imagined ethnic traditions soar.

In applying the above referred to approach it is claimed that the whole constitutional purpose of establishing unity and solidarity in our diverse society would be attained with more certainty. Achievement of unity and solidarity requires not mere toleration of difference, but institutional commitment towards accommodating difference.

\footnotetext{
${ }^{128}$ Ibid.

${ }_{130}^{129}$ Nedelsky (note 98 above) 13.

${ }^{130}$ Ibid.
} 